\title{
GAMBARAN PROSES RADANG LUKA POSTMORTEM PADA HEWAN COBA
}

\author{
${ }^{1}$ Patricius Geraldo Angel \\ ${ }^{2}$ Sonny Kalangi \\ ${ }^{2}$ Sunny Wangko
}

\author{
${ }^{1}$ Kandidat Skrispi Fakultas Kedokteran Universitas Sam Ratulangi Manado \\ ${ }^{2}$ Anatomi-Histologi Fakultas Kedokteran Universitas Sam Ratulangi Manado \\ Email: patriciusgeraldo@gmail.com
}

\begin{abstract}
Skin is the largest and heaviest organ in human body. Its role as a barrier and its location at the surface of human body make it susceptible to trauma which in consequence to wound formation. Human body responses to wound by initiating wound healing process. The fundamental aspect of this process consists of four phases: inflammation, initiation, proliferation, and remodeling. In order to obtain sucessfull wound healing all four phases must occur in a proper sequence and a time frame. Several factors have been known to interfere one or more of these phases. In postmortem condition, wound healing can still occur but the process is different compared to those in antemortem condition. A domestic pig was used on account of the similarity in skin structure and histophysiology with human being to observe the inflammatory process in postmortem wounds. This was an experimental descriptive research. Cut wounds were made at the back of the postmortem pig then skin tissues were taken and reserved in series of time to observe histological features of wound healing process. The results showed that an increase of cells' number in dermis layer of the skin was observed 15 minutes after the cut wounds. The increase of cells' number in the first wounds reached its peak at 150 minutes postmortem, meanwhile the increase of cells' number in second wounds reached its peak at 45 minutes postmortem, 90 minutes after the cut wounds were made. Moreover, the increase of cells'number could be observed until 3 hours postmortem. It was concluded that the inflammatory process of wound healing observed by increases of cells' number still occured postmortem for a certain time.
\end{abstract}

Keywords: Inflammatory process, postmortem, wound.

\begin{abstract}
Abstrak: Kulit merupakan organ terbesar dan terberat dari tubuh manusia. Keberadaannya yang membungkus seluruh permukaan tubuh sebagai fungsi proteksi menyebabkan kulit rentan terhadap trauma dan terjadinya luka. Ketika terjadi luka, tubuh manusia akan merespon dengan memulai proses penyembuhan luka. Secara umum, proses penyembuhan luka terdiri dari empat fase, yaitu fase inflamasi, inisiasi, proliferasi dan remodeling. Untuk terjadi penyembuhan luka dengan baik, fase penyembuhan luka ini harus berlangsung dengan urutan dan waktu yang tepat. Banyak faktor yang dapat mengganggu satu atau lebih fase ini. Dalam keadaan postmortem, penyembuhan luka masih dapat berlangsung, namun proses yang terjadi berbeda dengan penyembuhan luka sebelum kematian. Dalam penelitian ini digunakan babi domestik sebagai hewan coba karena babi termasuk hewan omnivora dengan struktur dan histofisiologi kulit yang mirip manusia. Penelitian yang dilakukan merupakan jenis penelitian deskriptif eksperimental. Luka sayatan dibuat pada punggung babi setelah mati lalu jaringan kulit diambil dalam beberapa tahapan waktu untuk melihat gambaran histologik sebagai penanda radang dalam proses penyembuhan luka. Hasil penelitian memperlihatkan bahwa peningkatan jumlah sel pada lapisan dermis terlihat sejak 15 menit setelah terjadinya luka. Peningkatan jumlah sel pada luka tahap pertama berlanjut dan memuncak pada 150 menit postmortem. Peningkatan jumlah sel pada luka tahap kedua berlanjut dan memuncak pada 45 menit yang diambil 90 menit setelah pembuatan luka. Proses inflamasi yang dinilai dari peningkatan jumlah sel pada penelitian ini tetap berlangsung sampai 3 jam postmortem. Penelitian ini memperlihatkan bahwa reaksi inflamasi tetap berlangsung normal pada kondisi postmortem untuk suatu tenggang waktu tertentu.
\end{abstract}

Kata kunci: Inflamasi, luka, postmortem. 
Kulit merupakan organ terbesar dan terberat dari tubuh manusia. Kulit dapat langsung diakses tanpa menggunakan alat bantu juga merupakan salah satu indikator terbaik dari kesehatan secara umum. ${ }^{1}$ Fungsi dari kulit antara lain: proteksi tubuh atas lingkungan, pembungkus struktur dan jaringan tubuh, regulasi suhu tubuh, sensasi, serta sintesis dan penyimpanan vitamin D. Fungsi kulit sebagai proteksi dan keberadaannya di permukaan tubuh menyebabkan kulit rentan terhadap trauma dan terjadinya luka. ${ }^{1-4}$

Luka didefinisikan sebagai diskontinuitas dari suatu jaringan atau keadaan hilang atau rusaknya sebagian dari jaringan tubuh. Kerusakan ini dapat disebabkan oleh trauma benda tajam dan benda tumpul, perubahan suhu, zat kimia, ledakan, sengatan listrik atau gigitan serangga. Apabila seseorang mengalami luka, tubuh akan merespon dengan memulai penyembuhan luka. Secara umum, respon tubuh untuk menyembuhkan luka terdiri dari tiga fase, yaitu fase inflamasi, proliferasi dan remodeling. $^{5-7}$ Ketika kerusakan jaringan yang terjadi minimal dan berlangsung singkat, dalam keadaan normal jaringan mampu untuk memperbaiki kerusakan yang terjadi sehingga hasil akhir yang terjadi biasanya berupa kembali normalnya fungsi serta histologik dari jaringan tersebut. ${ }^{8}$ Untuk terjadi penyembuhan luka dengan baik, fase penyembuhan luka ini harus berlangsung dengan urutan dan waktu yang tepat. Banyak faktor yang dapat mengganggu satu atau lebih fase ini yang kemudian akan mengganggu proses penyembuhan luka. ${ }^{9}$

Postmortem adalah keadaan setelah seseorang dinyatakan meniggal dunia. Pada postmortem ini, terjadi serangkaian proses pada tubuh tak terkecuali pada kulit. Penyembuhan luka pada postmortem masih dapat berlangsung, namun proses yang terjadi berbeda dengan penyembuhan luka sebelum kematian. ${ }^{10}$

\section{METODE PENELITIAN}

Jenis penelitian yang digunakan dalam penelitian ini adalah penelitian deskriptif eksperimental. Sampel yang digunakan merupakan hewan uji yaitu sus domecticus (babi domestik) dengan berat 20kg.

\section{PROSEDUR PENELITIAN}

1. Babi yang telah mati diletakkan dalam posisi terbaring menyamping

2. Alat dan bahan disiapkan

3. Bagian punggung babi dicukur dengan silet lalu dibersihkan dengan alkohol $70 \%$

4. Dibuat luka sayatan memanjang menggunakan bisturi pada pungung babi dengan kedalaman $1 \mathrm{~cm}$ dan panjang luka $3 \mathrm{~cm}$. Jarak antara satu luka dengan luka berikut sejauh $5 \mathrm{~cm}$.

5. Luka tahap pertama dibuat pada saat mati dan jaringan kulit diambil pada menit ke- 0, 15, 30, 45, 60, 90, 120, 150, dan 180.

6. Luka tahap kedua dibuat tiap 15 menit sampai 75 menit dan jaringan kulit diambil satu jam sesudah dibuat luka terakhir.

7. Dilakukan pengambilan sampel dan diberi kode lalu dilakukan fiksasi terhadap sampel yang sudah diambil dengan formalin $10 \%$.

8. Sampel yang sudah difiksasi kemudian dikirim ke Laboratorium Pusat Diagnostik Patologi Anatomi untuk pembuatan preparat.

9. Pembuatan preparat histologik dilakukan dilakukan dengan cara pemotongan memanjang mengikuti garis luka. Bagian luka pada kulit babi diberi warna untuk memudahkan pada proses identifikasi dengan mikroskop cahaya. Proses identifikasi luka difokuskan untuk melihat proses peradangan pada bagian epidermis dan dermis dari kulit disekitar luka. 
Angel, Kalangi, Wangko; Gambaran Proses radang Luka Post Mortem...

HASIL

Gambaran proses radang saat penyembuhan pada luka postmortem dapat dilihat pada Gambar 1-6.

Proses penyembuhan luka pada Gambar 1 A (0 menit postmortem) menunjukkan gambaran sebelum terjadi peningkatan jumlah sel sebagai tanda reaksi inflamasi. Terlihat lapisan tanduk serta beberapa sel pada lapisan epidermis dan dermis. Pada dermis terlihat serabut-serabut kolagen. Pada Gambar 1 B (setelah 15 menit postmortem), terlihat peningkatan jumlah sel inflamasi pada lapisan dermis.

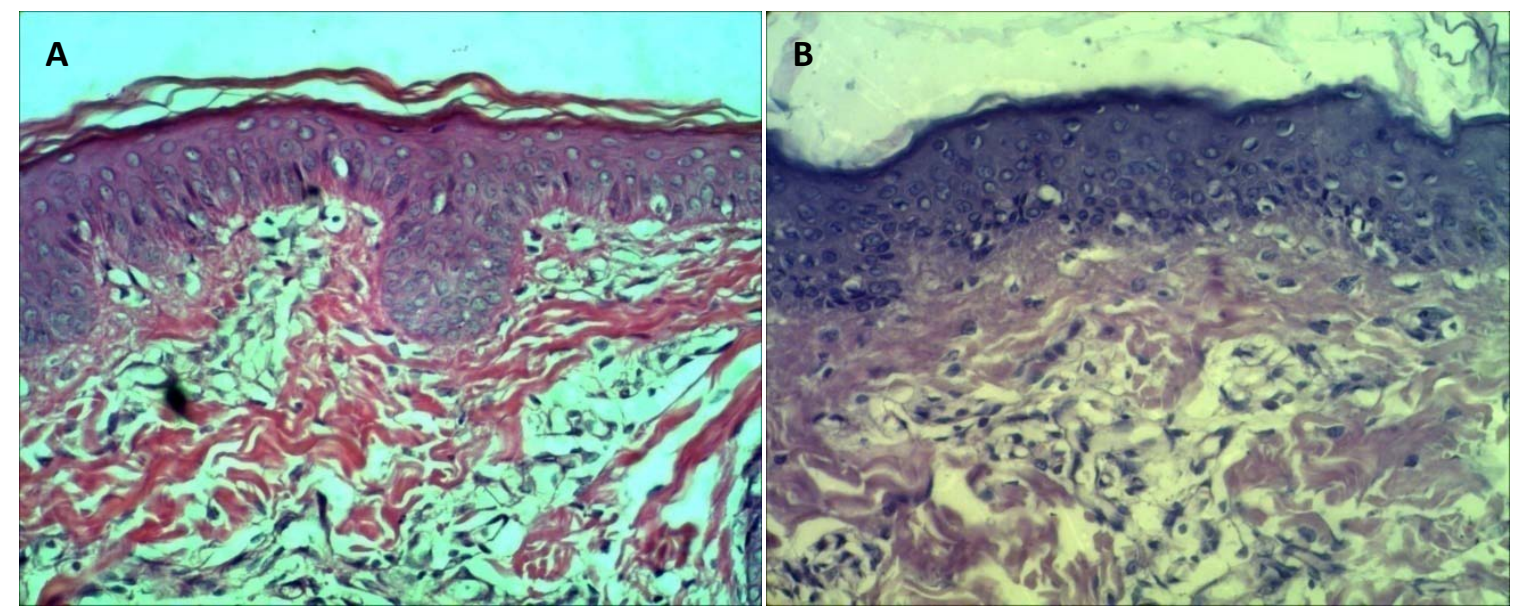

Gambar 1. Mikroskopik luka postmortem, (A) 0 menit postmortem (B) 15 menit postmortem
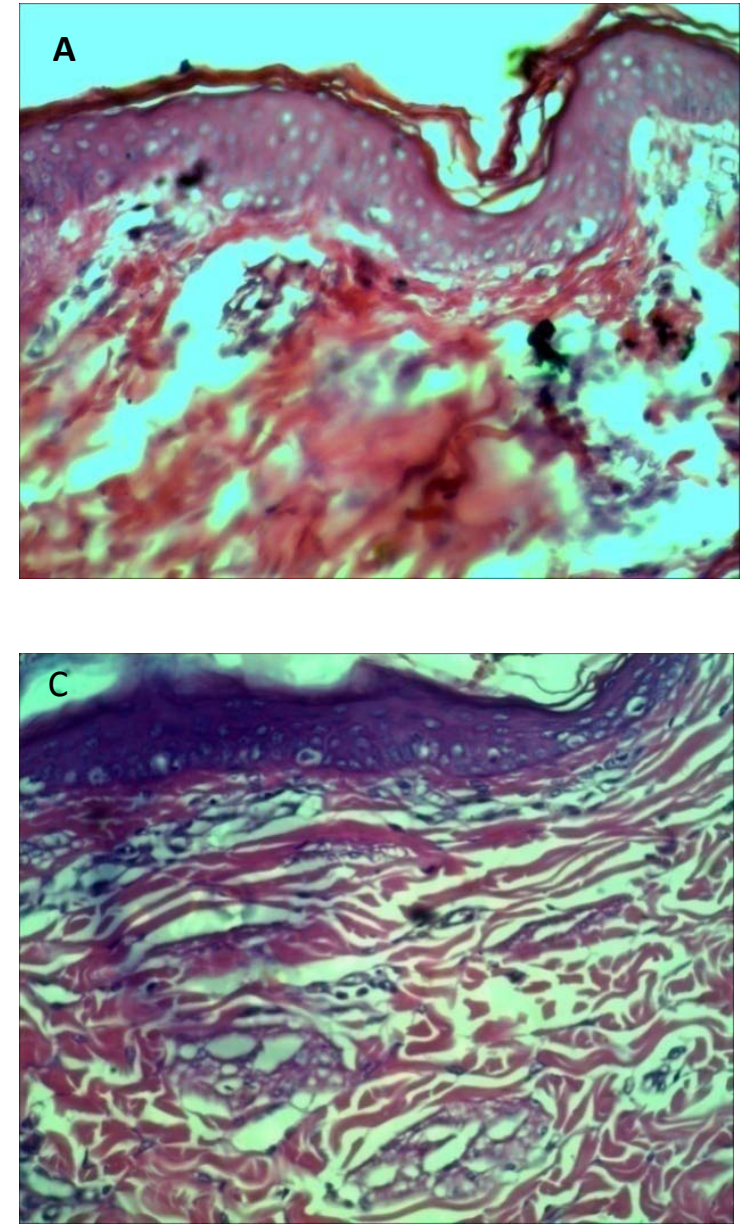

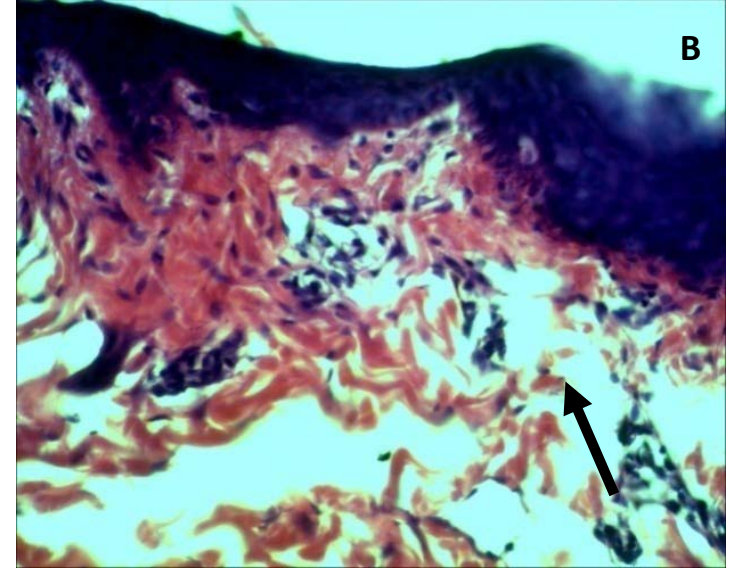

Gambar 2. Mikroskopik luka postmortem. (A) 30 menit postmortem, (B) 45 menit postmortem, (C) 60 menit postmortem.

Gambar 2 A, B, dan C secara berurutan menunjukkan peningkatan jumlah sel inflamasi. Sel-sel ini merupakan sel-sel inflamasi sebagai penanda reaksi inflamasi yang terjadi dalam proses penyembuhan luka. 

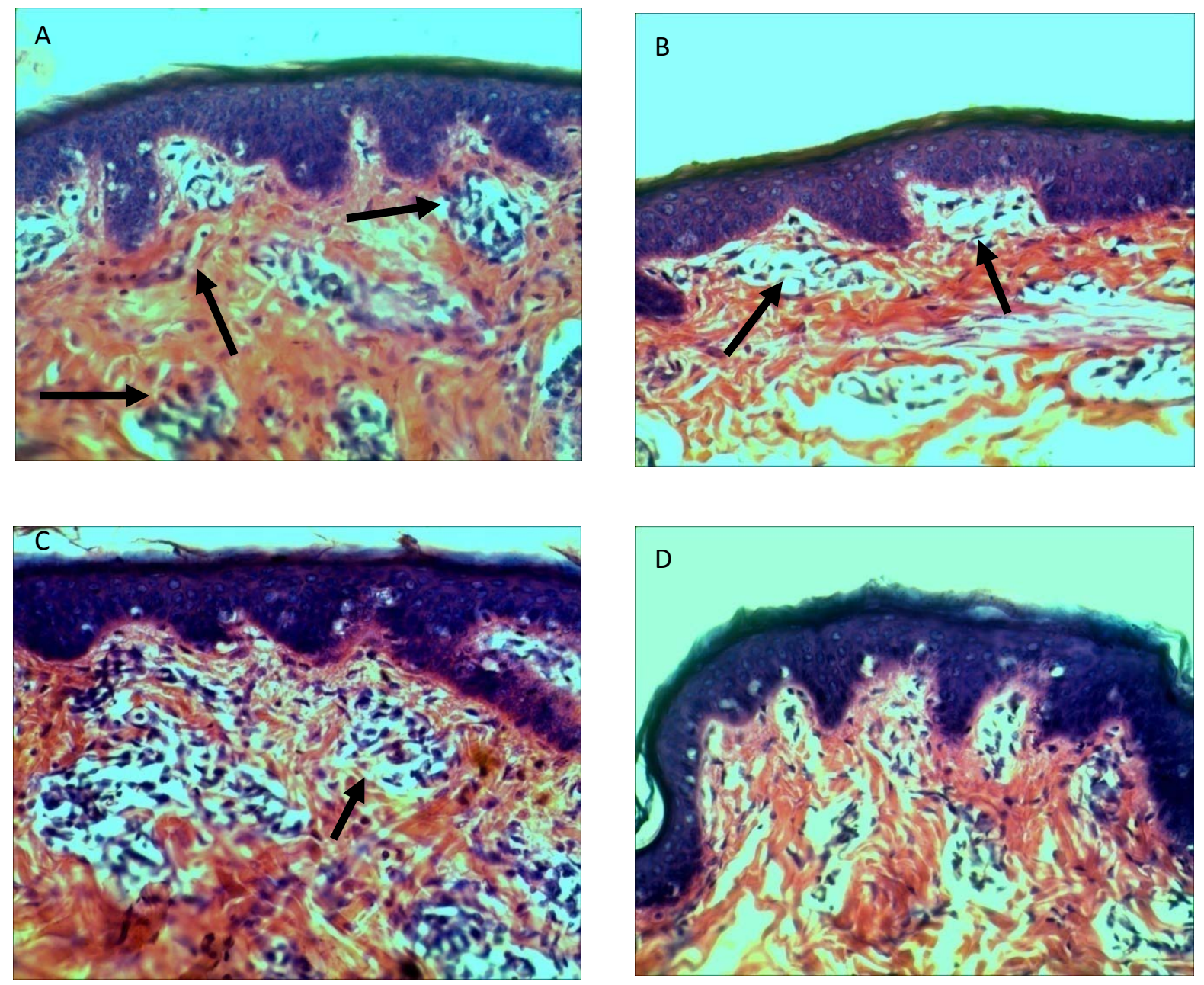

Gambar 3. Mikroskopik luka postmortem (A) 90 menit postmortem, (B) 120 menit postmortem, (C) 150 menit postmortem, (D) 180 menit postmortem.

Peningkatan jumlah sel inflamasi ini masih terus berlanjut pada Gambar 3 A (90 menit postmortem) dan 3 B (120 menit postmortem), lalu memuncak pada Gambar 3 C (menit ke-150 postmortem). Gambar 3 $\mathrm{D}$ (menit ke-180 postmortem) menunjukkan

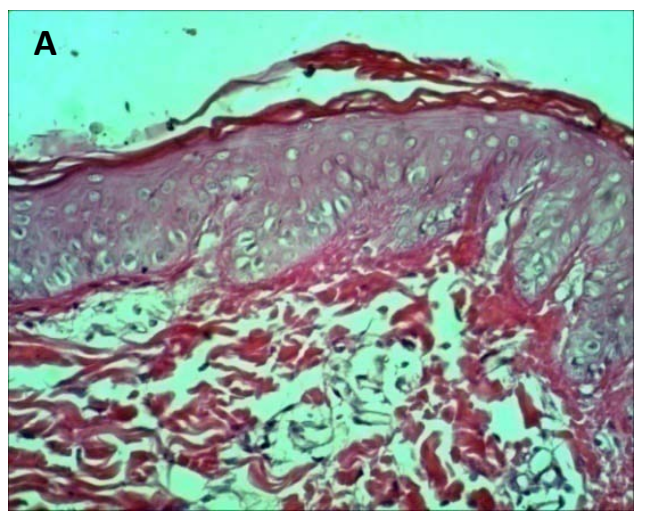

penurunan jumlah sel pada lapisan dermis dibandingkan Gambar 3 (A,B, dan C). Gambaran ini menunukkan proses inflamasi masih terus berlangsung, tetapi mulai menurun sampai sejak menit ke-150.

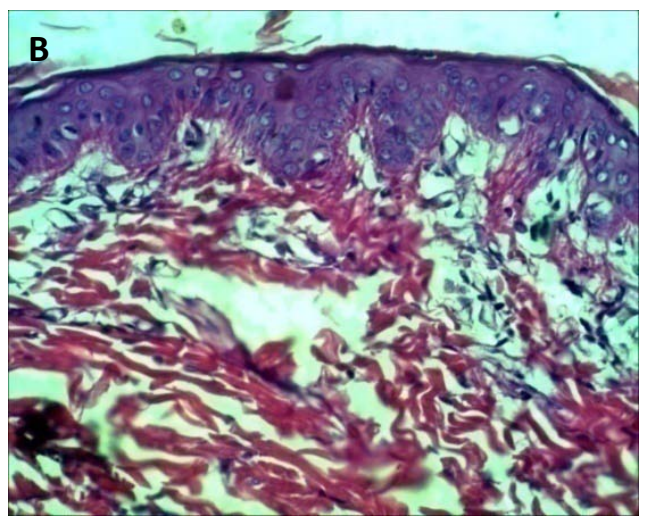

Gambar 4. Mikroskopik luka postmortem (A) 0 menit yang diambil 135 menit setelah pembuatan luka postmortem, (B) 15 menit yang diambil 120 menit setelah pembuatan luka postmortem. 
Angel, Kalangi, Wangko; Gambaran Proses radang Luka Post Mortem...

Gambar 4 merupakan luka yang dibuat bersamaan dengan pengambilan sampel pertama dan diambil setelah satu jam pembuatan sampel terakhir. Gambar 5 A $(0$ menit yang diambil 135 menit setelah pembuatan luka postmortem) menunjukkan gambaran dengan jumlah sel inflamasi yang sedikit. Gambar 5 B yang memiliki jeda 15

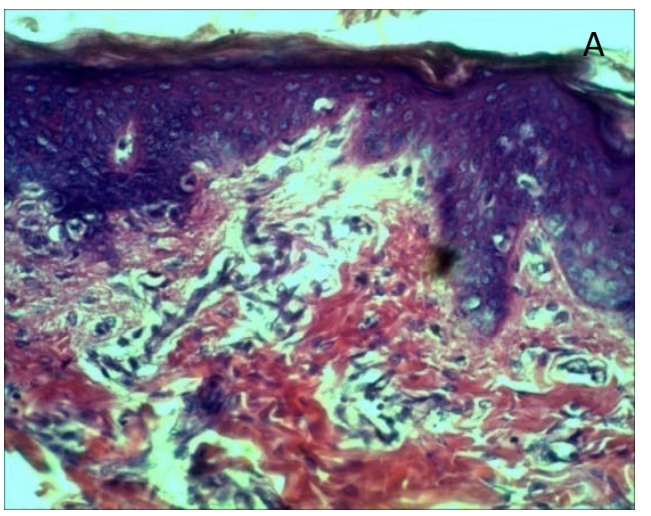

menit dengan sampel 10 menunjukan mulai ada peningkatan jumlah sel.

Gambar 6 A (30 menit yang diambil 105 menit setelah pembuatan luka postmortem) dan B (45 menit yang diambil 90 menit setelah pembuatan luka postmortem) masih menunjukkan pening-katan jumlah sel, dengan Gambar 6 B sebagai puncak.

Gambar 5. Mikroskopik luka postmortem (A) 30 menit yang diambil 105 menit setelah pembuatan luka postmortem, (B) 45 menit yang diambil 90 menit setelah pembuatan luka postmortem.
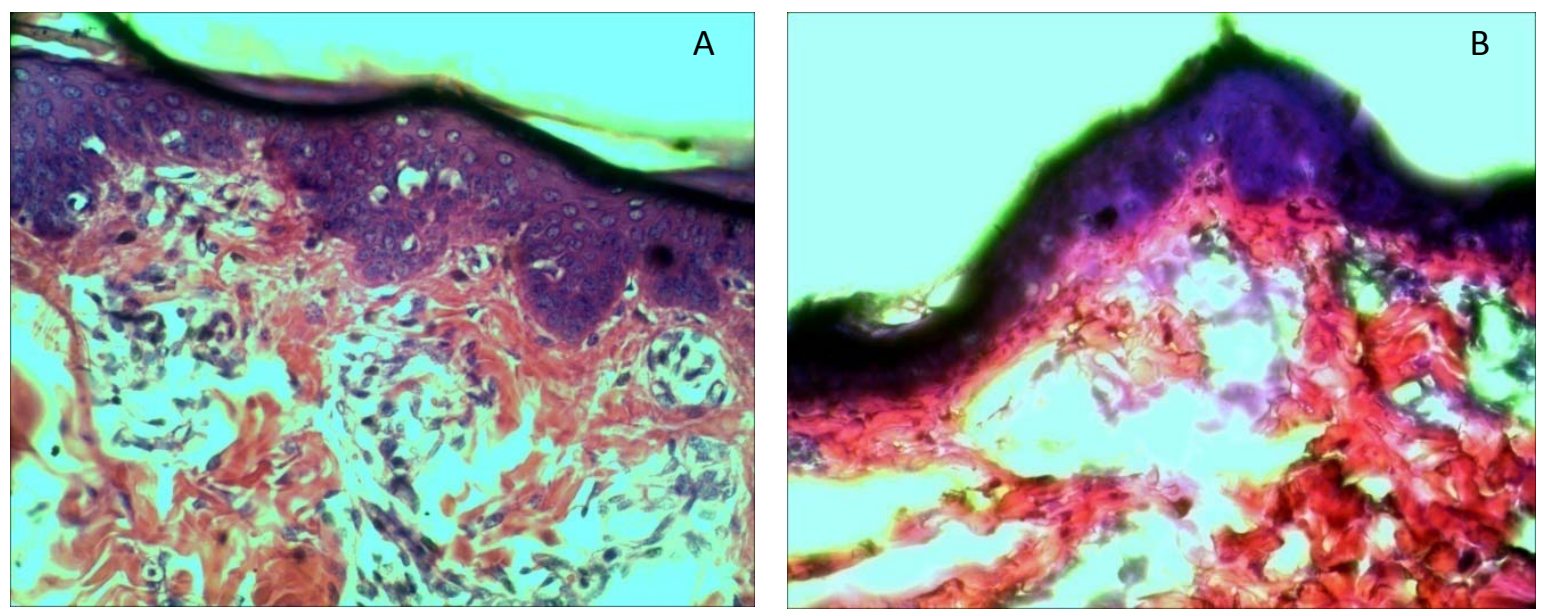

Gambar 6. Mikroskopik luka postmortem (A) 60 menit yang diambil 75 menit setelah pembuatan luka postmortem, (B) 75 menit yang diambil 60 menit setelah pembuatan luka postmortem

Mulai terjadi penurunan jumlah sel inflamasi pada Gambar 6 A, yaitu luka postmortem 60 menit yang diambil 75 menit setelah pembuatan luka postmortem. Gambar 6 B, yaitu saat 75 menit yang diambil 60 menit setelah pembuatan luka postmortem menunjukkan penurunan jum- lah sel lebih jauh dibandingkan sampel 14 .

\section{BAHASAN}

Penyembuhan luka merupakan proses yang kompleks dan sistematik. Faktor-faktor pertumbuhan mengatur migrasi, proliferasi, 
dan diferensiasi sel, juga sintesis dan degradasi protein matriks ekstrasel. Matriks ekstrasel secara langsung memengaruhi peristiwa seluler dan memodulasi sel yang berespons terhadap faktor-faktor pertumbuhan. Faktor-faktor fisik juga berperan dalam proses tersebut. Penyembuhan luka meliputi proses-proses sebagai berikut, yaitu: (1) induksi dari suatu respons radang akut oleh adanya cedera awal, (2) regenerasi sel parenkim, (3) migrasi dan proliferasi selsel parenkim dan sel sel jaringan ikat, (4) sintesis protein-protein matriks ekstrasel, (5) pembentukan kembali elemen-elemen parenkim untuk mengembalikan fungsi jaringan, dan (6) pembentukan kembali jaringan ikat untuk mencapai kekuatan luka. ${ }^{11}$

Fase inflamasi berlangsung sejak terjadinya luka. Respons inflamasi terhadap luka dimulai segera melalui kebocoran pasif dari sirkulasi leukosit (terutama netrofil) pada pembuluh darah yang terluka. ${ }^{19}$ Pembuluh darah yang terputus pada luka akan menimbulkan perdarahan sehingga tubuh akan berespon dengan mekanisme vasokonstriksi, pengerutan ujung pembuluh darah yang putus (retraksi) dan terjadi reaksi hemostasis. ${ }^{5-7}$

Inflamasi akut merupakan respon tubuh awal pada saat terjadi kerusakan jaringan. Terdapat dua komponen utama dari inflamasi. Pertama adalah perubahan vaskular yang berakibat pada terjadinya vasodilatasi dan peningkatan permeabilitas pembuluh darah. Kedua, perubahan seluler yang mengakibatkan emigrasi dan akumulasi leukosit pada tempat terjadi kerusakan jaringan yang dikenal dengan cellular recruitment and activation. Netrofil (leukosif polimorfonuklear) merupakan leukosit yang berperan utama alam keadaan inflamasi akut. ${ }^{12}$

Velnar T et al tahun 2009 meneliti subjek manusia antemortem dan men-dapatkan bahwa netrofil yang ditarik oleh berbagai agen kemoatraktif termasuk TGF- $\beta$, komponen komplemen seperti C3a dan C5a, dan peptida formiletionil mulai muncul di daerah luka dalam 24-36 jam setelah perlukaan. ${ }^{13}$ Menurut Shaw TJ et al, respons inflamasi dimulai segera setelah terjadinya luka melalui kebocoran pasif dari lekosit dalam sirkulasi (terutama netrofil) dari pembuluh darah yang terluka. ${ }^{14}$ Menurut Kim $\mathrm{MH}$ et al, netrofil ditarik ke daerah luka dan mulai teraktivasi ke luka dalam hitungan menit. ${ }^{15}$ Pada penelitian ini ditemukan ada peningkatan jumlah sel yang diasumsikan sel netrofil sebagai penanda inflamasi akut sejak 15 menit setelah terjadinya luka.

Dalam keadaan postmortem, oksigenasi dan perfusi terheti. Oksigen telah terbukti mempengaruhi proses penyembuhan luka melalui: mencegah terjadi infeksi, menginduksi angiogenesis, meningkatkan diferensiasi keratinosit, migrasi, dan reepitelisasi, meningkatkan proliferasi dan sintesis kolagen, dan mempromosi kontraksi luka. ${ }^{9}$ Namun, proses inflamasi yang dilihat dari peningkatan jumlah sel pada penelitian ini tetap berlangsung normal sampai 3 jam postmortem. Hal ini memperlihatkan bahwa reaksi inflamasi tetap berlangsung normal sampai beberapa jam postmortem

\section{SIMPULAN}

Gambaran histologik luka postmortem menunjukkan proses inflamasi dalam proses penyembuhan luka mulai terlihat sejak 15 menit setelah perlukaan. Pada jaringan hewan coba postmortem, masih tampak reaksi radang sampai tiga jam. Hal ini menunjukan bahwa dalam penentuan tanda intravital kedokteran forensik harus dipertimbangkan juga kemungkinan luka yang terjadi segera setelah kematian dan sesaat sebelum terjadi kematian.

\section{SARAN}

Diperlukan penelitian lebih lanjut dengan waktu yang lebih panjang untuk melihat gambaran histologik proses penyembuhan luka lanjutan dalam keadaan postmortem. Diperlukan variasi potongan luka agar mendapatkan gambaran luka yang lebih baik sehingga dapat terlihat proses yang lebih akurat 
Angel, Kalangi, Wangko; Gambaran Proses radang Luka Post Mortem...

\section{UCAPAN TERIMA KASIH}

Ucapan terima kasih disampaikan kepada dr. Sonny. J.R, MBiomed, PA(K), Dr. dr. Sunny Wangko, M.Si, PA(K) sebagai dosen pembimbing penulis serta $\mathrm{dr}$. Djon Wongkar, M.Kes, AIFO, dr. Shane H. R. Ticoalu, M.Kes, AIFO sebagai dosen penguji penulis dan Dr. dr. Erwin G. Kristanto, SH, SpF sebagai dosen penguji pakar juga bagi semua pihak baik yang secara langsung maupun tidak langsung telah menambahkan ide dan gagasan dalam pemikiran penulis sehingga dapat menyelesaikan artikel ini.

\section{DAFTAR PUSTAKA}

1. Moore KL. Clinically Oriented Anatomy, 5th ed. London: Lippincott Williams \& Wilkins, 2006.p.12-4.

2. Junqueira LC, Carneiro J. Basic Histology: Text \& Atlas, 11th ed. 2005.

3. Wasitaatmadja SM, Anatomi Kulit. Dalam: Djuanda A, editor. Ilmu Penyakit Kulit dan Kelamin. Edisi keenam. Jakarta: FKUI; 2013.h .3-5.

4. Structure and Function of the Skin. Diakses : 25 September 2013. Available from: http://www.hse.gov.uk/skin/professional/cau ses/structure.html

5. Perdanakusuma DS. Anatomi Fisiologi Kulit dan Penyembuhan Luka. Proceedings from caring to curing, pause before you use gauze; 2007 Sept 5; Surabaya, Indonesia. Indonesia; 2007.

6. Sjamsuhidajat R, Wim de Jong, luka dan penyembuhan luka buku ajar ilmu bedah edisi 3. Jakarta: EGC, 2003. h. 95-120.
7. Keast D, Orsted H. The basic principles of wound healing. Diakses: 25 September 2013. Available from: http://cawc.net/images/uploads/Principlesof-Wound-Healing.

8. Anonimus. Acute Inflammation. Kumar, Abbas, Fausto, Mitchell, editors. In: Robbins Basic Pathology, 8th ed. Elsevier Inc. 2008. Hal 33-43.

9. Guo S, DiPietro LA. Factors Affecting Wound Healing. J Dent Res. 2010. 89(3): 219-29.

10. Idries AM, Pedoman Ilmu kedokteran forensik. Edisi pertama. Jakarta : Binarupa Aksara, 1997.h, 54-63.

11. Kalangi SJR. Peran integrin pada angiogenesis penyembuhan luka. Cermin Dunia Kedokteran. 2011; vol 38:177-180.

12. Obac AR, Carvalho EG, Silva PCS, Fenerich-Verani N, Almeida $M$. Histological Analysis of short-term vital reactions in skin wounds: potential applications in forensic work. Braz. J. Biol., 2011; 71(4): 1011-14.

13. $\mathrm{T}$ Velnar, $\mathrm{T}$ Bailey and $\mathrm{V}$ Smrkolj. The Wound Healing Process: An Overview of the Cellular and Molecular Mechanisms. Journal of International Medical Research, 2009; 37: 1528.

14. Shaw TJ, Martin P. Wound Repair At a Glance. Journal of Cell Science, 2009; 122: 3209-13.

15. Kim MH, Curry FRE, Simon SI. Dynamics of neutrophil extravasation and vascular permeability are uncoupled during aseptic cutaneous wounding. Am J Physiol Cell Physiol. [cited 24th Feb 2014] 2009; 296(4): C848-C856. Available at: http://www. ncbi.nlm.nih.gov/pmc/articles/PMC267065/ 